\title{
Poor and Unhygienic Nutrition in Schools of District Lower Dir, Khyber Pakhtunkhwa, Pakistan
}

\author{
Ghulam Nabi (Corresponding author) \\ Master of education, Alkhair University, AJK, Pakistan \\ Email: ghulamnabiqau@gmail.com \\ Tariq Aziz \\ Master of education, Alkhair University, AJK, Pakistan
}

Muhammad Imtiaz Aqdas

Faculty of business administration, Alkhair University, AJK, Pakistan

Nasrullah Khan

Faculty of business administration, Alkhair University, AJK, Pakistan

Aziz ur Rahman

SST, GHSS, Chakdara, Lower Dir, Khyber Pakhtunkhwa, Pakistan

Saima

Master of education, Alkhair University, AJK, Pakistan

\section{Noor U1 Hassan}

PET, GHSS, Zimdara Maidan, Lower Dir, Khyber Pakhtunkhwa, Pakistan

Received: May 14, 2016 Accepted: May 30, 2016

doi:10.5296/jbls.v7i2.9461 URL: http://dx.doi.org/10.5296/jbls.v7i2.9461 


\section{Abstract}

Proper qualitative and quantitative nutrition is very crucial for both physical and mental development of children. School going children need special attention with respect to their nutrition need as, poor and unhygienic nutrition not only have serious effects on physical and mental growth, but also compromises cognitive behavior. Some developed countries have formulated special lunch food programs for school children and is under strict control. However, in developing countries there is no such policy. This review article focuses on the food items mostly served and their possible consequences in the schools of Pakistan especially in district Lower Dir.

Keywords: Behavior, Cognitive, Lower Dir.

\section{Introduction}

In the mid- $19^{\text {th }}$ century, for the first time school meal provision start due to public health response to under-nutrition and subsequently poor health of children. But in late $20^{\text {th }}$ century due to emergence of obesity epidemics in children, the focus for public health changed (Caroline Walker Trust, 1993). It has been found that what children eat at home is paramout, still school plays a key role in assisting children establish healthier choices; (School Meals Review Panel, 2005; Jaime and Lock, 2009; Story, 1999) within this school meals are central, both as a means of providing nutrition to children regardless of social background. Childhood obesity can be effectively prevented in schools by providing an environment that especially included healthy school meals and food (Katz et al., 2008; Katz, 2009). In Canada and USA, Nutrition Detectives ${ }^{\mathrm{TM}}$ program is very active in hundreds of school regarding children school nutrition (Katz, 2006). School lunch directly affect the diet of children who have school lunches. Other factors such as, lunch time and food choice also affect the diet and health of children (Ashley et al,.). But in the developing countries like Pakistan no any organization and no serious attentions has been given to healthy school food. Present review article is based on the hazardous effect of school food practiced in Pakistan especially in the province Kyber Pakhtunkhwa, district Lower Dir.

\section{Relationship between School Nutrition and Children}

There is a correlation between cognition as well as psychosocial behaviour and nutrition. Many studies have found that various vitamins, proteins and food substances can affect learning brain physiology (Amy, 2010). The brain is affected by nutrition as the amino acids and choline let the neurotransmitters such as, norepinephrine, dopamine, acetylcholine and serotonin in actions. To make the right amount of choline and amino acids, food consumption is very crucial (Colby-Morley, 1981; Growden and Wurtman, 1980). Nutrition can also affect cognition as a correlation has been reported between poor school performance and poor nutrition (Wood, 2001). Nutrients such as, iron and zinc has been linked with short attention spans and low memory (Wood, 2001). Lack of protein in school children not only leads to low school performance but can cause children to be lethargic, passive and withdrawn, all these affect emotional and social development (Erickson, 2006). Similarly, fluctuating levels of carbohydrates can affect cognitive performance due to mental confusion 
and dizziness. On the other hand, eating carbohydrate rich food enhances tryphtophan absorption, which increases serotonin secretion, leading to more calm and relax mood (Erickson, 2006). Fats make up more than $60 \%$ of the brain. Omega-3 fatty acids is very crucial for the optimum brain performance and lack of these fats can leads to ADD, dyslexia, learning disabilities, low IQ, poor memory and depression (Erickson, 2006). In Australia, children were given drinks with Omega-3 fatty acids along with vitamin C, B12, B6, A and iron, zinc and folic acid. Such children showed high scores on tests measuring memory, learning skills and intelligence (Wolpert \& Wheeler, 2008). According to the Dietary Guidelines for Americans (DGA) meal must contain one third of the RDA of protein, vitamin A, vitamin C, iron, calcium, and calories (Amy, 2010)

\section{Nutritional Status in Pakistani Schools}

In Pakistan, especially in Dir Lower, a district in Khyber Pakhtunkhwa province no proper qualitative and healthy food is given to school children during relaxation time. School children especially from public schools are not allowed to go to home for food. On the other hand, most of these children belong to distant areas; they even cannot go but have also early breakfast every day. The only foods mostly available for these children in schools are; local biscuits, toffees, chocolates, snacks, gums, cakes, lollipops and churan. Such foods are not only poor in nutrition but due to low quality can cause serious problems in children. Local food colour additives can cause serious health problems as, the blue colours (paten blue E131 and brilliant blue E133) can enter the blood stream and can cause disruption of cell metabolism especially inhibiting mitochondrial respiration. Lollipops, hard candies and related products are too long in in contact with tongue mucous membrane and can penetrate directly into the blood stream undecomposed. Further, these colours are also partially decomposed in GIT after oral intake. These colors have been linked with asthma, allergies and ADHD (attention deficit hyperactivity disorders) (Oliver, 2013).

Chocolates and candies are related with pleasure and joy, potentially being antidepressant, relaxant and stimulant (Macht and Mueller, 2007; Parker et al., 2006). But, due to the addition of various ingredients and complex formulations, risk of heavy metal contamination increases in candies and chocolates. Dahiya et al. (2005), Rankin et al. (2005) and Skrbic et al.(2013) found considerable concentrations of $\mathrm{Pb}, \mathrm{Cd}$, and $\mathrm{Ni}$ in candies and chocolates. Further, if these chocolates are local (unbranded) there is high chances of even more contamination that can leads to serious health consequences. Such types of local products are very common in this province and contamination especially metal contamination can occur in any stage of processing, raw materials, packaging, transportation and storage. In some instances, heavy metals contamination in chocolates and candies can occur from the migration of packaging to food stuff by direct or indirect contact (Duffy et al. 2006; Johns et al. 1996; Laoubi and Vergnaud 1996). Pb mostly found in chocolates and candies can cause peripheral nervous disorders, fatigue head ache and anaemia (Rankin et al. 2005), cancer and kidney and liver problems when taken in excess (IARC, 1990). However, at low concentration, it can cause learning disabilities and health problems (Parmila et al., 2016). Similarly, high concentration of $\mathrm{Ni}$ is hepatotoxic, neurotoxic, nephrotoxic, pulmonary toxic, imunotoxic and hematotoxic (Nielson and Flyvholm, 1984) and can also lead to dizziness, 
weakness, nausea and bronchial haemorrhages (Parmila et al., 2016). Short-term and long-term exposure to high levels of $\mathrm{Cd}$ in food items can cause kidney-related problems, shocks, liver injury convulsions, sensory disturbances, salivation, muscle cramps, diarrhoea, vomiting and nausea (Rajappa et al., 2010). Regular consumption of candies and chocolates may increases the consumption of fats in diet, weight gain (Mursu et al. 2004) and hyper cholesterolemia (Wan et al., 2001). A variety of local spicy chips and snacks are very common in schools of district Lower Dir. It has been known that these spicy chips and snacks can increases stomach acidity and can cause gastritis, stomach pain, nausea and vomiting. In some districts of New Mexico, these spicy chips and snacks have banned because of their low nutritional value. According to some scientists these spicy chips have some addictive quality that is why kids like too much them (Lecia, 2013). Some children bring food such as bread from home wrapped in newspapers. Such foods not only get contaminated from dust and other thing but also absorb various chemicals from the newspapers that can pose serious health problems.

In summary, school children of district Lower Dir are exposed to unhygienic and poor nutrition in school. Both food and education department should take strict actions against these local companies. Such foods should be chemically analysed. Further, school children should be aware from the hazardous effects of these food items and healthy food like fruits should be encouraged. Education department should design a policy regarding food quality for school children.

\section{References}

Amy, Ross. (2010). Nutrition and its effects on academic performance how can our schools improve?. PhD Thesis. 1-58.

Ashley, A. Martin, W. Martin, S. Suzanne, S. Jennifer, D. Elaine, S. John, M. Douglas, E. The process and impact of change in the school food policy on food and nutrient intake of children aged 4-7 and 11-12 years both in and out of school; a mixed methods approach. Public Health Research Consortium.

Caroline Walker Trust. (1993). Nutritional guidelines for school meals: report of an expert working group.

Colby-Morley, E. (1981). Neurotransmitters and nutrition. Orthomolecular Psychiatry, 12, $38-43$.

Dahiya, S. Karpe, R. Hegde, A. G. Sharma, R. M. (2005). Lead, cadmium and nickel in chocolates and candies from suburban areas of Mumbai, India. Journal of Food Composition and Analysis, 18(6), 517-522.

Duffy, E. Hearty, A. P. Gilsenan, M. B. Gibney, M. J. (2006). Estimation of exposure to food packaging materials. 1: development of a food-packaging database. Food additives and contaminants, 23(6), 623-633.

Erikson, J. (2006). Brain food: the real dish on nutrition and brain function. Wis Kids Journal, Novemeber/December. 
Growdon, J. H. Wurtman, R. J. (1980). Contemporary nutrition: nutrients and neurotransmitters. New York State Journal of Medicine. September.

IARC (1990). Chromium, nickel and welding. IARC Monographs on the Evaluation of Carcinogenic Risks to Humans, 49, 1-648.

Jaime, P. C, Lock, K. (2009). Do school based food and nutrition policies improve diet and reduce obesity? Preventitive Medicine. 48. 45-53.

Johns, S. M. Jickells, S. M. Read, W. A. Gramshaw, J. W. Castle, L. (1996). Studies on functional barriers to migration: use of model substances to investigate transfer from paper and board packaging to food. Deutsche Lebensmittel- Rundschau, 92(9), 273-278.

Katz, D. (2010). School nutrition programs: nutrition detectives; 2006. Available at: http://www.davidkatzmd.com/nutritiondetectives. aspx. Accessed September 7, 2010.

Katz, D. L. (2009). School-based interventions for health promotion and weight control: not just waiting on the world to change. Annu Rev Public Health. 15, 15.

Katz, D. L., O’Connell, M. Njike, V. Y. Yeh, M. C. Nawaz, H. (2008). Strategies for the prevention and control of obesity in the school setting: systematic review and meta-analysis. Int J Obes (Lond). 32(12).1780-1789.

Laoubi, S. Vergnaud, J. M. (1996). Theoretical treatment of pollutant transfer in a finite volume of food from a polymer packaging made of a recycled film and a functional barrier. Food Additives \& Contaminants, 13(3), 293-306.

Lecia, B. (2013). Spicy Chips, Cheetos Inflame Your Mouth... And Your Stomach. Medical daily.http://www.medicaldaily.com/spicy-chips-cheetos-inflame-your-mouth-and-your-stoma ch-263038. (Accessed on 12 May 2016).

Macht, M. Mueller, J. (2007). Immediate effects of chocolate on experimentally induced mood states. Appetite, 49(3), 667-674.

Mursu, J. Voutilainen, S. Nurmi, T. Rissanen, T. H. Virtanen, J. K. Kaikkonen, J. Salonen, J. T. (2004). Dark chocolate consumption increases HDL cholesterol concentration and chocolate fatty acids may inhibit lipid peroxidation in healthy humans. Free Radical Biology and Medicine, 37(9), 1351- 1359.

Nielson, F. H. Flyvholm, M. (1984). Risk of high nickel intake with diet. In: Nickel in the Human Environment, Proceedings of the Joint Symposium, Lyon 8-11 March, Lyon International Agency for Research on Cancer, IARC Scientific Publication, 53, (pp. 333-338). Nutrition, 74(5), 596-602.

Olive, N. (2013). Blue colors in lollipops present health risk to kids, say researchers. http://www.confectionerynews.com/Regulation-Safety/Blue-colors-in-lollipops-present-healt h-risk-to-kids-say-researchers. Accessed on 12 May, 2016.

Parker, G. Parker, I. Brotchie, H. (2006). Mood effects of chocolate. Journal of Affective Disorder, 92, 149-159 


\section{Macrothink}

Parmila, D. Vandana, B. Garg, V. K. Suman, M. Khaiwal R. (2016).. Heavy metal content in various types of candies and their daily dietary intake by children. Environ Monit Assess, 188:86.

Rajappa, B. Manjappa, S. Puttaiah, E. T. (2010).Monitoring of heavy metal concentration in groundwater of Hakinaka Taluk, India. Contemporary Engineering Sciences, 3(4), 183-190.

Rankin, C. W. Nriagu, J. O. Aggarwal, J. K. Arowolo, T. A. Adebayo, K. Flegal, A. R. (2005). Lead contamination in cocoa and cocoa products: isotopic evidence of global contamination. Environmental health perspectives, 113(10), 1344-1348.

School Meals Review Panel. (2005). Turning the Tables. Transforming School food: A report on the development and implementation of nutritional standards for school lunches.

Skrbic, B. Zivancev, J. Mrmos, N. (2013). Concentrations of arsenic, cadmium and lead in selected foodstuffs from Serbian market basket: estimated intake by the population from the Serbia. Food Chemical Toxicology, 58, 440-448.

Story, M. (1999). School based approaches for preventing and treating obesity. International Journal of Obesity Related Metabolic Disorders. 23(2).43-51.

Wan, Y, Vinson, J. A. Etherton, T. D. Proch, J. Lazarus, S. A. Kris-Etherton, P. M. (2001). Effects of cocoa powder and dark chocolate on LDL oxidative susceptibility and prostaglandin concentrations in humans. The American journal of clinical

Wolpert, S., Wheeler, M. (2008). Food as brain medicine. UCLA Magazine Online. Retrieved http://magazine.ucla.edu.

Wood, M. (2001). Studies probe role of minerals in brain function. Agriculture Research, 49.10 .

\section{Copyright Disclaimer}

Copyright for this article is retained by the author(s), with first publication rights granted to the journal.

This is an open-access article distributed under the terms and conditions of the Creative Commons Attribution license (http://creativecommons.org/licenses/by/3.0/). 